
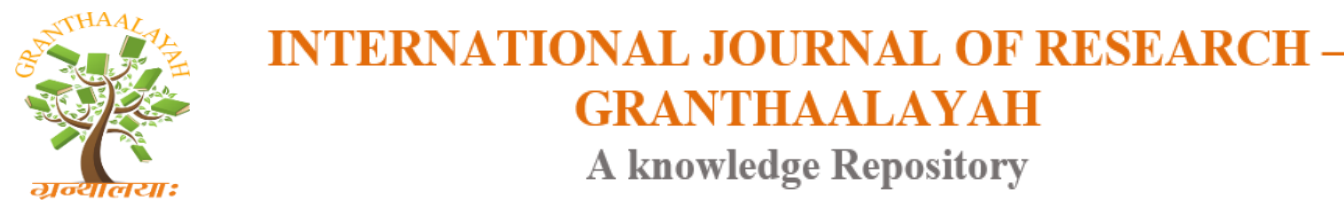

Science

\title{
DYNAMICS OF GROWTH OF ALBIZIA ADIANTHIFOLIA AND ALBIZIA ZYGIA (TWO LOCAL LEGUMINOUS PLANTS WITH RAPID GROWTH) DURING THE REGENERATION OF THE POST-FARMING FALLOW AND DEGRADED SPACES
}

\author{
Kouassi Kouadio Henri ${ }^{1}$, Kouassi Roland Hervé ${ }^{2}$, Amon Ano Denis-Esdras ${ }^{1}$ \\ ${ }^{1}$ University of Jean Lorougnon Guédé laboratory of Vegetable Biology \\ ${ }^{2}$ Department of Sciences and Technology, life and Earth Science Section, normal high school of \\ Côte-d'Ivoire, 08 BP 10 Abidjan 08
}

\begin{abstract}
The threat which is on the forests and wooded spaces of Africa and particularly those of Côte d'Ivoire is accentuated over the years. The quoted leading causes are the land pressure related to demography, the anarchistic exploitation of the forest woody plants and itinerant agriculture. In many cases, the afforestation is the recommended palliative measure. But with which woody plants does one retimber in Côte d'Ivoire? Which assessment are previous initiatives made? On several occasions the exotic woody plants with rapid growth were used without success. The main objective of this study is to identify local woody plants with rapid growths of which the use will contribute to a significant degree to fast regeneration of our forests, degraded spaces and the postfarming fallow. Floristic inventories and measurements were carried out on the stems of Albizia adianthifolia and Albizia zygia in elementary plots of $400 \mathrm{~m}^{2}(20 \mathrm{~m} \mathrm{X} \mathrm{20m).} \mathrm{Two} \mathrm{local} \mathrm{arborescent}$ Leguminous plants with rapid growth were identified for this purpose. They were: Albizia adianthifolia and Albizia zygia. The experiments showed that these species reach the maximas of their growth in height and thickness as from nine (9) years. The sowing of the fallow and/or spaces degraded by these woody species supports the fast regeneration of these degraded spaces.
\end{abstract}

Keywords: Côte D'ivoire; Albizia; Regeneration; Leguminous Plant; Rapid Growth.

Cite This Article: Kouassi Kouadio Henri, Kouassi Roland Hervé, and Amon Ano Denis-Esdras. (2018). "DYNAMICS OF GROWTH OF ALBIZIA ADIANTHIFOLIA AND ALBIZIA ZYGIA (TWO LOCAL LEGUMINOUS PLANTS WITH RAPID GROWTH) DURING THE REGENERATION OF THE POST-FARMING FALLOW AND DEGRADED SPACES." International Journal of Research - Granthaalayah, 6(9), 364-372. https://doi.org/10.5281/zenodo.1451870.

\section{Introduction}

The leading causes of degradation of natural spaces are inter alia: land pressure related to demography (Kouassi, 2007), the anarchistic exploitation of the forest woody plants and itinerant 
agriculture. The afforestation is the palliative measure recommended over the years to correct these losses in biodiversity. But with which woody plant does one retimber in Côte d'Ivoire? Which assessment are previous initiatives made?

In Côte d'Ivoire, the repeated army and politic crises supported the evolution of the last cause quoted above. Indeed, during the ten years of crisis, the exploitation of the exploited woody plants known a fulgurating evolution. On several occasions the exotic woody plants with rapid growth were used. It was the case of Acacia mangium and Acacia auriculiformis in the south of Côte d'Ivoire (Dupy and guéssan, 1990). These afforestations were carried out to restore the agricultural soils and to solve the problem of deficit out of wood energy. However, many afforestation campaigns are directed towards the local forest woody plants each year thus showing the limits of the afforestation containing exotic woody plants and the need for developing the local woody plants. Indeed, the use of the exotic woody plants does not preserve in all the cases, the biodiversity. These species with closed canopy often inhibit on the court, means or long time the development of the heliophilous forest plants still to the state of seed in the underwood.

The main objective of this study is thus to characterize two local Leguminous plants with rapid growths (Albizia adianthifolia and Albizia zygia) of which the use will contribute to a significant degree to regenerate the flora of the forests and other degraded ecosystems. In addition, the experiment showed that in Côte d'Ivoire, the participative diagnosis is very effective for the control and the success of work in rural environment; especially when it is the integration and the adoption of new cultivation systems. The investigations of Kouassi (2003) in rural environment showed the adoption of these leguminous plants by the bordering populations of the Tonkpi mount. Indeed, in their farming practices, the peasants of this locality protect these plants which they leave in partnership with the cultures. In addition, work of Akobundu (1995) and Kouassi et al. (2008) showed that these two local Leguminous plants with rapid growth support forest regeneration and could be used like means of effective fight against the deforestations in the forest mediums. Moreover, by their capacity (symbiotic fixing of atmospheric nitrogen) to improve the fertility and the physicochemical properties of the soils, these woody plants can be used for the sowing of the fallow in rural environment for the improvement of their productivity. Also, the improvement of the productivity of the fallow in rural environment is an effective means to fight against deforestation and forest fragmentation. The species studied in the present study have not only the advantage of having a rapid growth but also, that of the restoration of the soils by symbiotic association with bacteria of the Rhizobium genus. The rapid growth of these species can be put at profit in the afforestation campaigns for the fast regeneration of the degraded mediums. Their capacity to restore the fertility of the grounds makes them, very useful woody plants for the integrated management of the soils in rural environment. Moreover, these local species have the advantage of being in balance with the natural environment unlike certain exotic arborescent Leguminous plants (Albizia lebbeck, Albizia guachapele, Acacia mangium, etc.), whose introduction involves sometimes the regression of the local or indigenous flora (Gnahoua, 1997). However, the use and the integration of these species in the programs of afforestation can be done only by the known of their growth and their development. This study is primarily based on the analysis of the horizontal (density) and vertical (average heights) structure, of the settlements of Albizia zygia et Albizia adianthifolia in fallow of spread out ages. 


\section{Material and Methods}

The study proceeded in Oumé (Mid-west), in semi-deciduous zone forest of Côte d'Ivoire (Fig 1). The Department of Oumé is located at $260 \mathrm{~km}$ to Abidjan, $\left(6^{\circ}\right.$ et $7^{\circ}$ of Northern latitude and $5^{\circ}$ et $6^{\circ}$ of Western longitude). In this sector, 45 fallow of 1 to more than 50 years, with surfaces varying of 1 with more than 3 ha, comprising Albizia adianthifolia and Albizia zygia were divided into unit plot of $50 \mathrm{~m} \mathrm{X} 50 \mathrm{~m}\left(2500 \mathrm{~m}^{2}\right)$ and into under plots of $400 \mathrm{~m}^{2}$ (fig. 2). Floristic inventories and measurements were carried out on the stems of Albizia adianthifolia and Albizia zygia and those of the other arborescent ligneous family. The parameters of strengths (height, diameter with height of chest) were estimated. During measurements, only the individuals of more than $2 \mathrm{~m}$ height and $20 \mathrm{~cm}$ of circumference were taken into account. Three vegetable formations of more than 70 years presenting the ultimate stages of reconstitution (climax) were selected like references plots. The plots were all installed on Clay-sandy soils.

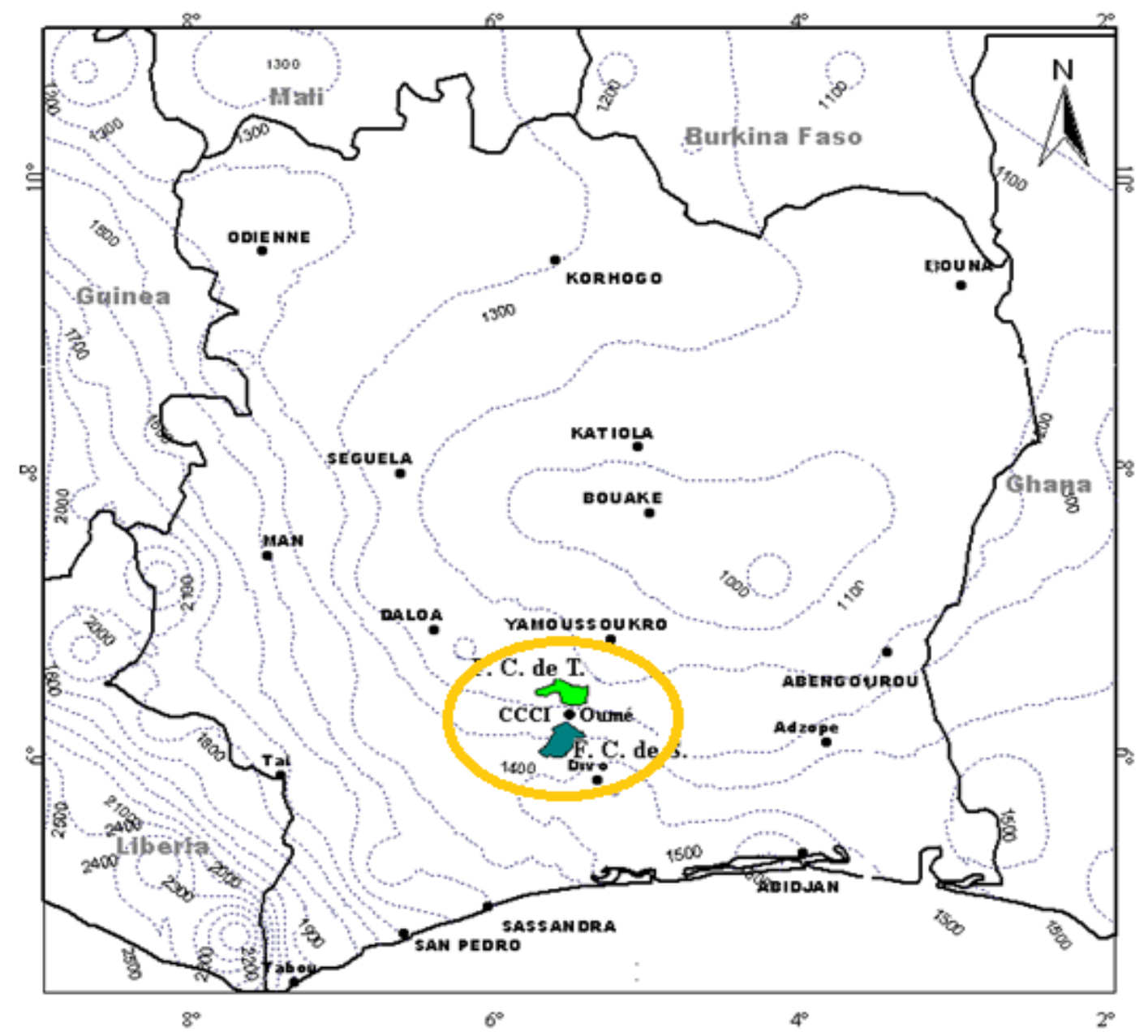

Figure 1: Localization of the zone of study (Source: Monnier, 1983)

Site of the study 


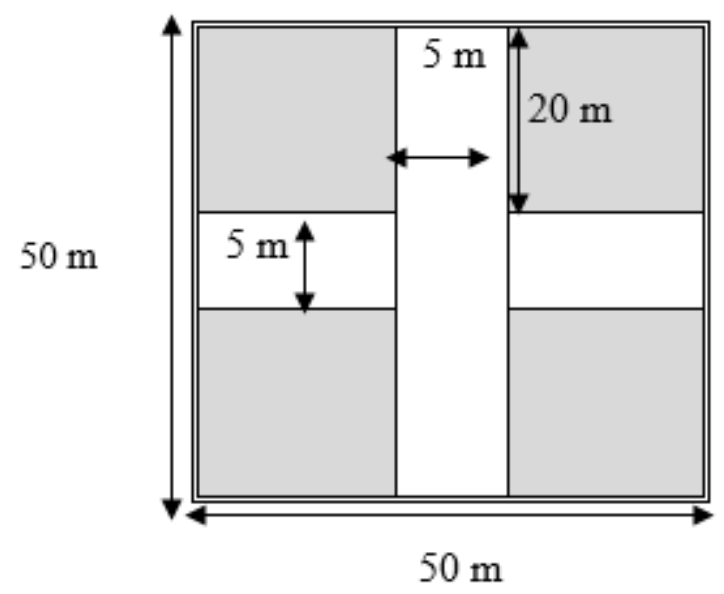

Figure 2: Configuration of the inventoried plots

\section{Results and Discussion}

\subsection{Results}

\subsubsection{Evolution of the Density of Albizia Adianthifilia in the Course of Time in Different the Various Vegetable Formation}

The polynomial regression (fig. 3) showed that curved density of Albizia adianthifolia evolves out of bell; with a light ascent at the beginning of fallow (1 to 5 years). At this stage, the average densities, vary between 0 and 80 stems/ha. The maximum density ( $275 \mathrm{stems} / \mathrm{ha})$ was obtained in 10 years of fallow. This density decreases thereafter and reaches: $215,150,115$ and 30 stems/ha after 11,15,20,55 years of fallow.

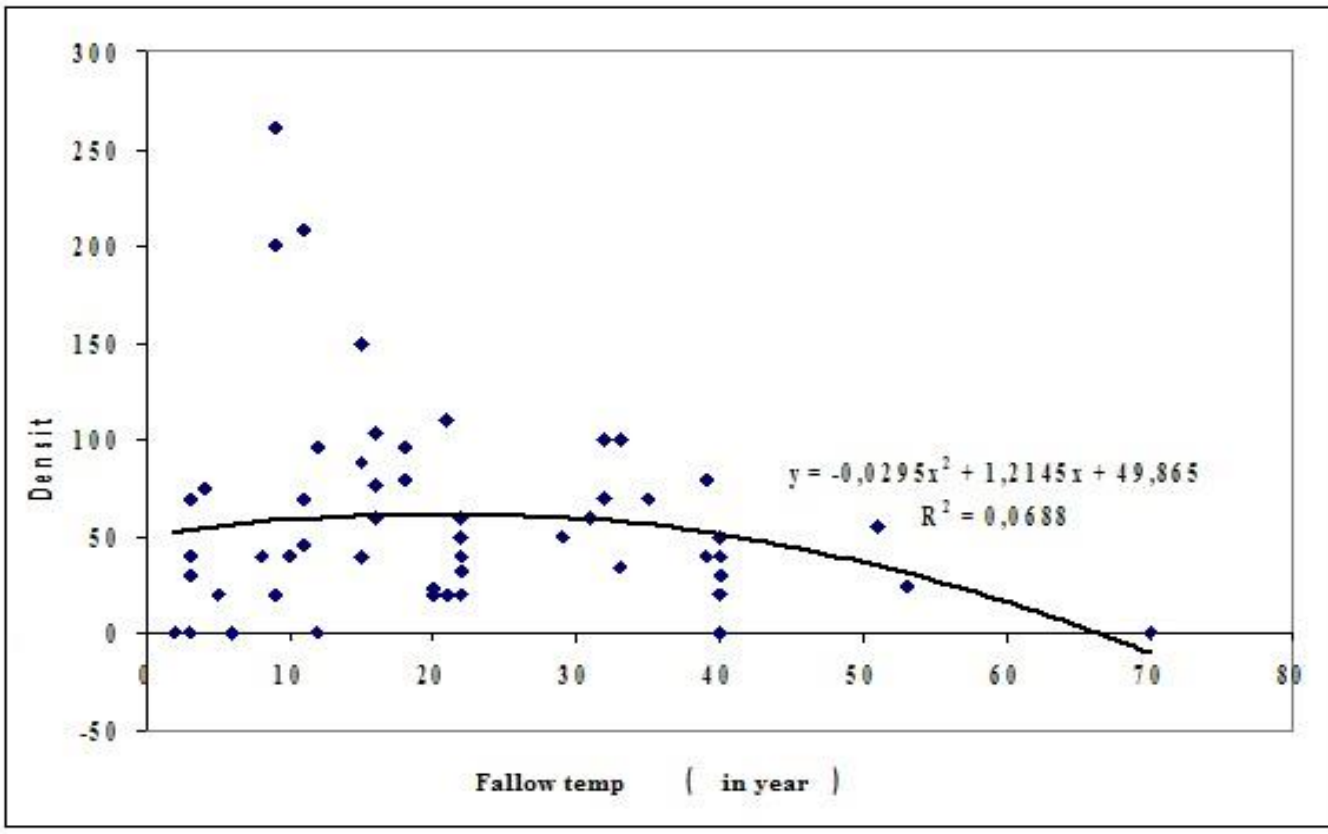

Figure 3: Evolution of the density of Albizia adianthifolia in the course of time 


\subsubsection{Evolution of the Density of Albizia Zygia in the Course of Time in the Vegetable Formations}

The curve of the density of Albizia zygia (fig. 4) evolves out of bell, with a light ascent at the beginning of fallow ( 1 to 5 years). The estimated values are about 100 and 115 stems/ha in 5 years of fallow. The average densities obtained into 9 and 15 years of fallow are respectively about 175 stems/ha and 495 stems/ha. This density decrease slightly after 15 years of fallow and passes to 400, 200, 150 even 60 stems/ha to respectively in 20,30,40,50 years of fallow. The high densities (550 and 515 stems/ha) of Albizia zygia are obtained between 15 and 20 years.

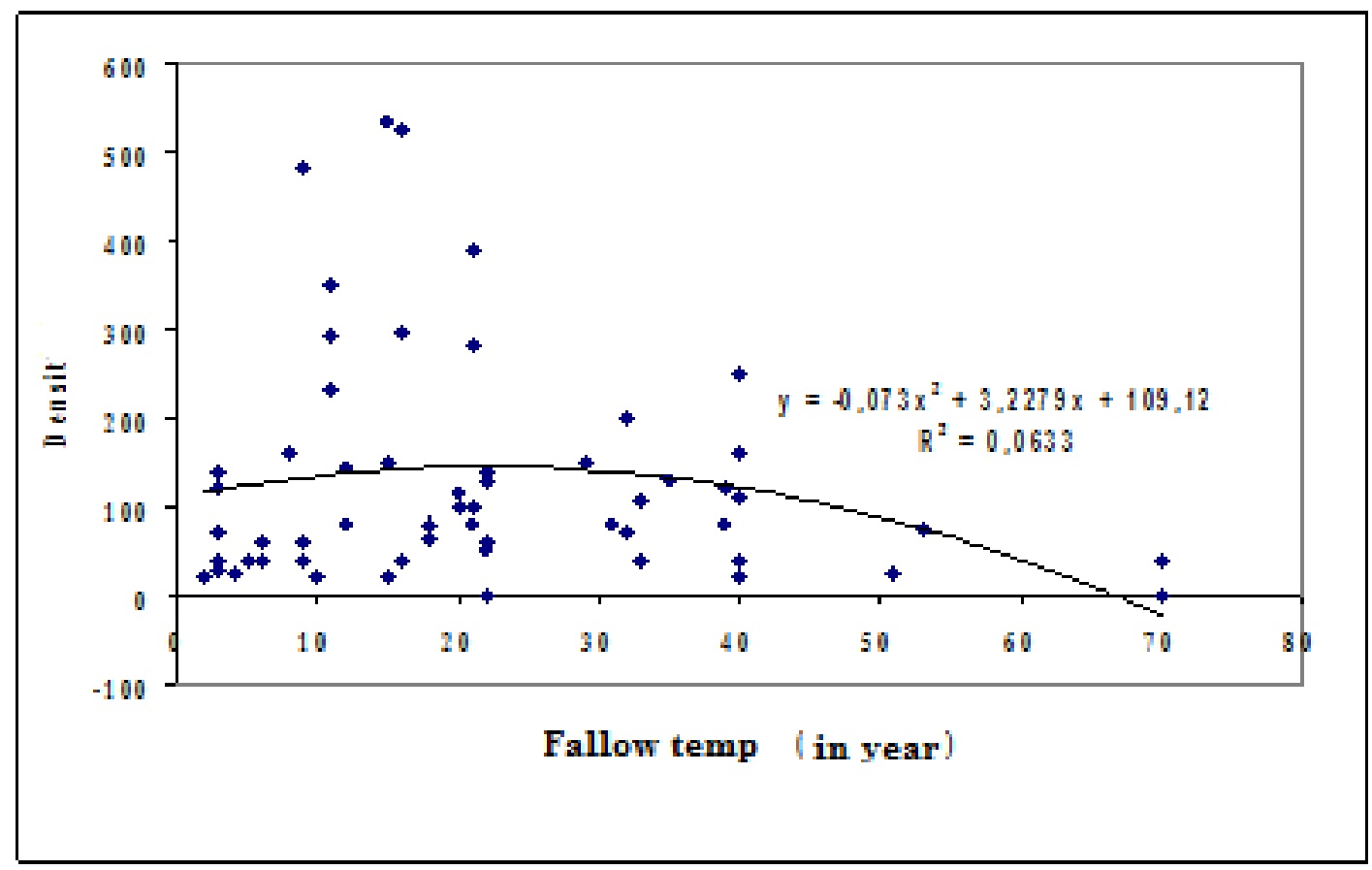

Figure 4: Evolution of the density of Albizia zygia in the course of time

\subsubsection{Evolution of the Average Height of Albizia Adianthifolia and Albizia Zygia in the Course of Time}

The evolution of the curve of the average height of Albizia adianthifolia (fig. 5) comprises 4 phases. The first, increasing, begins between 0 and 5 years and is completed between 11 and 20 years, with average heights of about 7 to 15 meters. the second decreasing, extends from 11 to 20 and from 21 to 30 years, with respective average heights estimated at 8 and 15 meters. the third phase corresponds to a light increase of the average height of Albizia adianthifolia and Albizia zygia between 31 and 40 years. The fourth phase is that which is located beyond 40 years phase during which the average heights of the both species fall gradually. The high average heights are reached between 11 and 20 years. The evolution of the average heights of Albizia zygia (fig. 6) comprises also 4 phase. The first extends over the period from 0-5 and is completed between 1120 years. During this phase the recorded average heights are about 0, 7,8 and 16 meters. the second phase extends over the period from 11-20 and 21-30 years, with a light decrease of the average heights of the order estimated at 15.5 meters. The third corresponds to a light increase of the 
average height between 31 and 40 years. The last phase is that which extends beyond 40 years. The high average heights are obtained between 11 and 20 years.

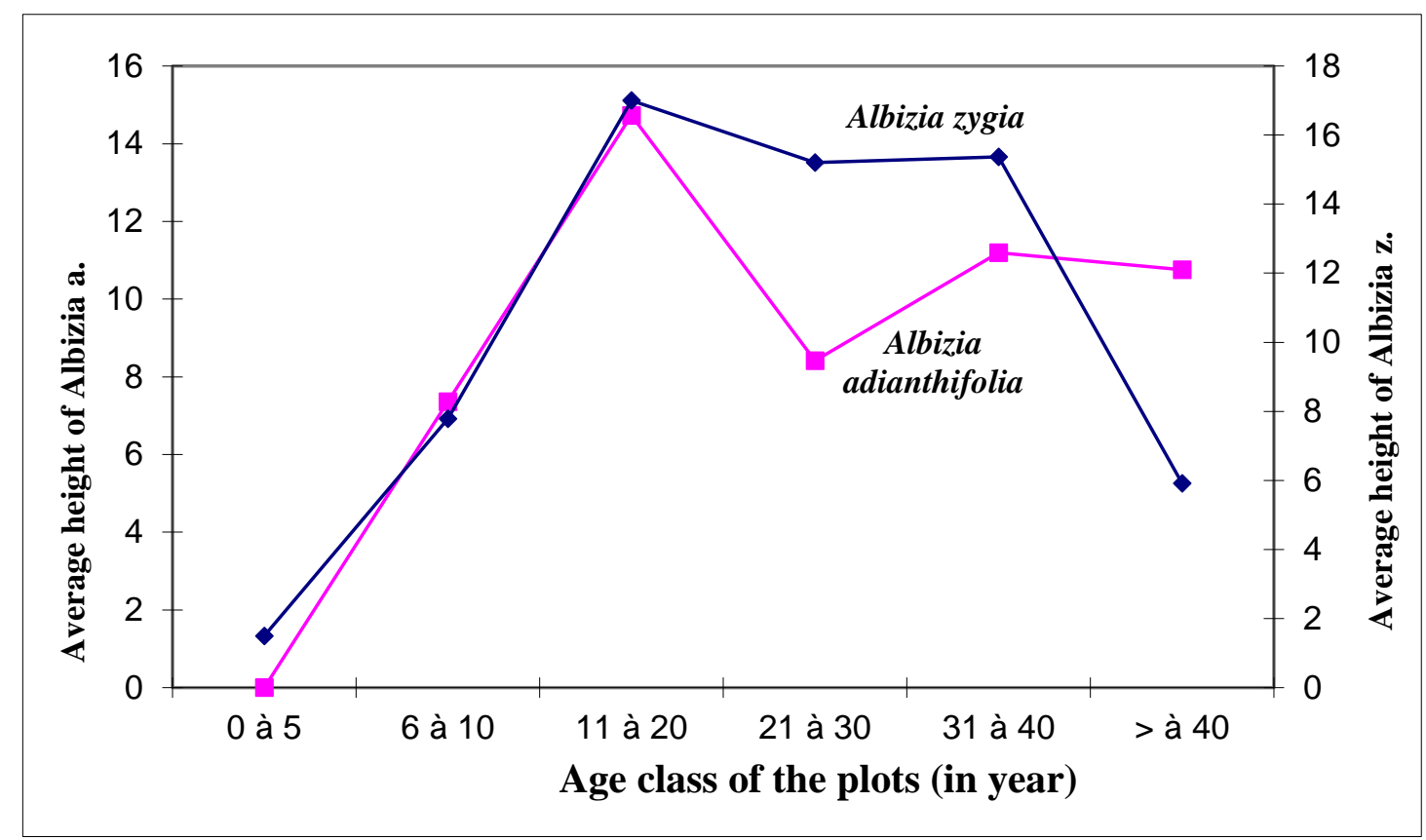

Figure 5: Evolution of annual average heights of Albizia zygia and Albizia adianthifolia in the curse of the time

\subsubsection{Evolution of the Average Annual Increase in Thickness of Albizia Adianthifolia And Albizia Zygia}

The evolution of the curve of the annual average growth in thickness of Albizia adianthifolia increase (Fig. 6) comprises 2 great phases. The first phase is ascending and extends from 0-5 years, 6-10 years and 11-20 years, with average annual increases of about $0.01 ; 0.04$ and $0.06 \mathrm{~m} / \mathrm{an}$. The second, decreasing, begins between 11-20 years then continues between 21-30 years, becomes stationary between 21-30 years, 31-40 years and is completed beyond 40 years, with respective values of about $0.06 ; 0.02 ; 0.02$ and $0.01 \mathrm{~m} / \mathrm{an}$. In addition, the maximum average increase is obtained between 11-20 years with $0.06 \mathrm{~m} /$ year. On the other hand the average annual increase in Albizia zygia (Fig. 6) comprises three phases: two increasing phases, and one phase decreasing. The increasing phase extends from 0-5 years, 6-10 and 11-20 years, with average annual increases respective of about $0 ; 0.04$ and $0.07 \mathrm{~m}$ /year. The second increasing phase extends from 31-40 years and to more than 40 years, with average increases of about $0.03 ; 0.04 \mathrm{~m} /$ year. The decreasing phase begins from 11-20 years and continues between 21-30 years and 31-40 years, with annual increases respective average in $0.07 ; 0.05$ and $0,03 \mathrm{~m} / \mathrm{an}$. The high annual increase average $(0.07$ $\mathrm{m} / \mathrm{an}$ ) is reached between 11-20 years. 


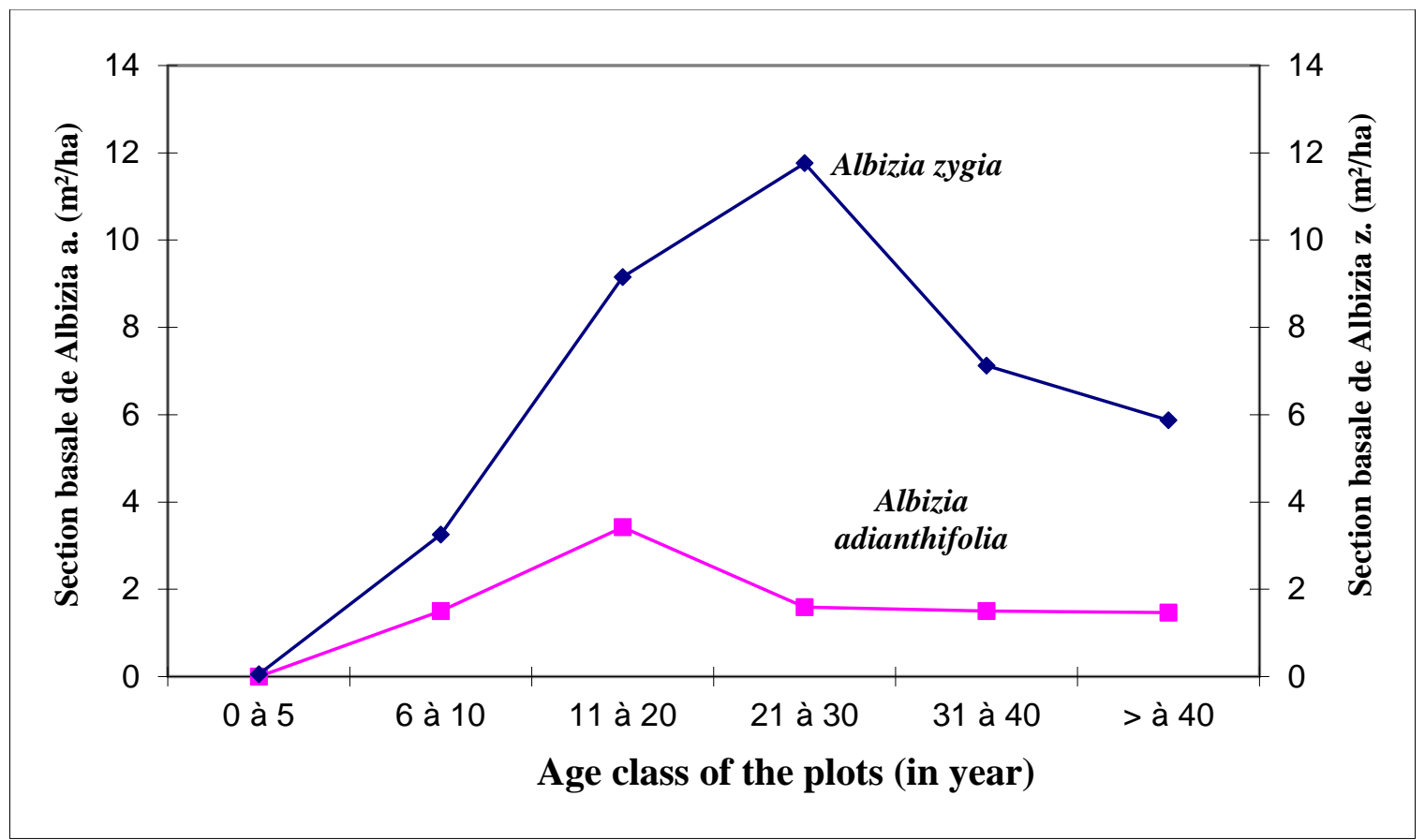

Figure 6: Evolution of annual average growth in thickness of Albizia zygia and Albizia adianthifolia in the curse of the time

\section{Discussion}

\subsection{Evolution of the Density of Settlement of Albizia Adianthifolia and Albizia Zygia}

The results showed that the number of stems of Albizia adianthifolia and Albizia zygia growths regularly between 5 and 20 years of fallow. This quick change is due to the capacity of regeneration of the both arborescent Leguminous plants. Indeed, these species regenerate not only starting from the stocks but also and especially by seed. Moreover, under the favorable conditions the seeds are mainly viable as it was mentioned by Alexandre (1989) in forest zone of Côte d'Ivoire and Donfack (1993) in zone of transition forest-savanna of Cameroum. Also, the massive presence from these species is an indicator of the aptitudes of these species at the interspecific competition.

\subsection{Evolution of the Average Height of Albizia Adianthifolia Et and Albizi Azygia in the Course of Time}

In the inventoried vegetable formations, the both Albizia reach more than $10 \mathrm{~m}$ heights in 6-11 years and the high height in 11-20 years. This rapid growth is characteristic of the majority of Leguminous plants as it was mentioned by Barima (2004), Kouassi et al. (2013) and Gnahoua (1997). Indeed, the capacity of these Leguminous plants to fix symbiotic nitrogen is a major asset which contributes to a significant degree to the improvement of the agronomic properties of the soil. In addition, the large bushes of Chromolaena odorata wich inhibit the development of heliophilous numerous species (forest species) do not constitute an obstacle to the development of these Legume trees. Indeed, at the youthful stage, these species have the ability to behave midshade-loving in cash, mid-heliophilous until they arrive to surpass the other species of the flora 


\subsection{Evolution of the Annual Average Increase in Thickness of Albizia Adianthifolia and Albizia Zygia}

The many development strategies worked out by these two Legume trees constitute the key of their rapid growth in height and thickness. Indeed, Alexandre (1989) and Kouassi (2008) showed that besides the modification of their energy needs at the youthful stage, these species also behave at this stage like lianas and is pressed on tutors to emerge from the canopy. Once at this stage these species make regress other species of the flora in particular, Chromolaena odorata through the canopy which they form quickly. Thus, the regression of certain species supports a greater availability of the nutritive resources of the plants. This regression improves the conditions of development; what facilitates the growth in thickness of the trees

\section{Conclusion}

This study which principal objective is to characterize two local Leguminous plants with rapid growths of which the use will contribute to a significant degree to regenerate the flora of the forests of Côte d'Ivoire and other ecosystems degraded showed that the evolutions of the parameters of growth and development (densities, growth in thickness and growth in height) of both species studied are similar. Indeed, the high average growths of the two species are obtained between 11 and 20 years. On the other hand, the minimal growths range between 0 and 5 years. These results confirmed the possibility of integrating both legume trees studied in the campaigns of afforestation and by rebound in effective management of the natural forests. However, a good planning of multidimensional studies for a rational management of these woody plants is necessary to improve their agronomic performances in order to lead to their optimal and durable use. It is also a way of solution to cope with the wood energy strong demand. This is why, in the future it will be necessary to think of the introduction of these two legume trees among the species used for the fast regeneration of the forests in Côte d'Ivoire. These species are among those which are adapted better to the climate changes and have many advantages of which the maintenance of the endemic flora.

\section{References}

[1] Akobundu I.O and Agyakwa C W. Guide des adventices d'Afrique de l'Ouest. (Eds) IITA, Ibadan, Nigeria, 1989, $522 \mathrm{p}$.

[2] Alexandre D. Y. Dynamique de la régénération naturelle en forêt dense de Côte d'Ivoire. Etudes et Thèses, Orstom Paris 1989 a, 102 p.

[3] Barima Y.S. S. Dynamique de croissance et production de biomasse aérienne des légumineuses arborées en zone forestière d'Oumé. Mémoire de DEA de Botanique, option: Ecologie végétale, Côte d'Ivoire, Université de Cocody, Laboratoire de Botanique, 2004, 49 p.

[4] Donfack P. Etude de la dynamique de la végétation après abandon de la culture au Nord Cameroun. Thèse de doctorat de $3^{\mathrm{e}}$ cycle, Université de Yaoundé, 1993, $180 \mathrm{p}$

[5] Dupy B. et N'guesan K. Sylviculture de l'Acacia mangium en Côte d'Ivoire, CTFT, Côte d'Ivoire, 1990.

[6] Gnahoua G.M.. Analyse phytoécologique de la flore adventice des cultures post-jachères améliorées en zone de forêt semi-décidue de Côte d'Ivoire, D.E.A. Ecosystèmes terrestres et méditerranéennes, Université Aix-Marseille III, 1997, 34 p

[7] Kouassi K.H. Caractérisation des systèmes de production de la région semi montagneuse de 1'Ouest Ivoirien : cas du secteur des villages riverains du Mont Tonkpi dans le Département de Man. Mémoire de D.E.A., UFR Biosciences, Université de Cocody-Abidjan, Côte d'Ivoire, 2003, 95 p 
[8] Kouassi KH.; Traore D. et Gnahoua G. M. Dynamique des peuplements d'espèces locales de légumineuses arborescentes dans la reconstitution des friches post-culturales en zone de forêt semidécidue de côte d'Ivoire: les cas de Albizia adianthifolia (Schumah) W. F. Wrigth et de Albizia zygia (DC.) J. F. Macbr. Agronomie Africaine (AGRON. AFR., 19 (2), 2007 103-231 125-135

[9] Kouassi K.H., Sangne YC., N'guessan K.. Dynamics of Woody Species during the post-harvest regeneration in semi-deciduous forest of Côte d'Ivoire, J.B.A.H.S.,Vol.2 (3): 2013, 62-67

[10] Monnier Y. Hydrologie, végétation, les sols. Jeune Afrique, Atlas de la Côte d'Ivoire., $2^{\grave{e}}$ édition, 1983, 10-21.

*Corresponding author.

E-mail address: atoumanikouadiokan@yahoo.fr/krolandherve@yahoo.fr 